\title{
Comparison and correlation of visual inspection with acetic acid, papanicolaou smear and colposcopy in detection of precancerous cervical lesions
}

\author{
Manju Talathi,* Girija Wagh
}

Department of Obstetrics and Gynaecology, Bharati Vidyapeeth medical College, Pune, Maharashtra, India

Received: 25 July 2016

Accepted: 26 August 2016

*Correspondence:

Dr. Manju Talathi,

E-mail: manjutalathi@yahoo.in

Copyright: (c) the author(s), publisher and licensee Medip Academy. This is an open-access article distributed under the terms of the Creative Commons Attribution Non-Commercial License, which permits unrestricted non-commercial use, distribution, and reproduction in any medium, provided the original work is properly cited.

\begin{abstract}
Background: Cervical cancer is a huge emotional and financial burden on society. To curb the disease, there is a need to develop a screening test that has good sensitivity and specificity. The present study is aimed to compare the effectiveness of the Pap smear, visual inspection with acetic acid (VIA) and colposcopy for mass screening of premalignant and malignant lesions of the cervix. The objective of this study was to screen women of 30-45 years of age for precancerous cervical lesions with VIA, Pap smear and colposcopy. And compare and correlate the findings of Pap smear, colposcopy and VIA in detecting precancerous lesions of cervix.

Methods: This was a prospective observational study conducted from 1 January 2015 till 1 June 2016 (36 months) in OPD, department of obstetrics and gynaecology among 500 women of 30-45 years. of age group. Pap smear was performed by the conventional method and then VIA was carried out for all; colposcopy was done in all VIA positive patients.

Results: Out of 500 study group, 364 (72.8\%) women were VIA negative and 136 (27.2\%) were VIA positive. Pap results in VIA negative women were either NILM or normal, none was with intraepithelial lesions. Out of 136 VIA positive women 42 (34\%) pap results were LSIL or HSIL and on colposcopy 59 (44.7\%) women had CIN I/II/III.

Conclusions: These results establish VIA as an effective screening test for cancerous and precancerous conditions of the cervix and thus VIA can be implemented as a single primary screening method. Colposcopy can further interpret the VIA positive lesion with almost $100 \%$ sensitivity, specificity, NPV in high grade lesions.
\end{abstract}

Keywords: Pap smear, VIA, Colposcopy, Precancerous lesion of cervix, NILM, LSIL, HSIL

\section{INTRODUCTION}

Cervical cancer has huge burden on national health system. ${ }^{1,2}$ Cervical cancer kills approximately 230,000 women annually, with the vast majority of deaths occurring in developing countries. Worldwide, cervical carcinoma is the fifth most common cancer-related cause of death among women in the developing world; it is the leading cause of cancer death in women. ${ }^{1}$
Global distribution of cervical cancer varies, with Africa, Asia, and Latin America bearing a substantial burden of this disease. ${ }^{1,2}$

Cervical cancer prevention programs in both developed and developing nations generally have relied on cytological testing using the papanicolaou (Pap) smear test. Such screening programs can be expensive, prone to error, and logistically difficult to implement particularly in developing countries. 
Research worldwide has clearly shown that virtually all cervical cancer is caused by human papillomavirus (HPV) infection. The direct detection of HPV in cervical specimens may offer an alternative or complement to population-based cytological screening. But using HPV testing as a primary screening modality is expensive.

Papanicolaou (Pap) smear is the primary screening tool for cervical intraepithelial neoplasia (CIN) and invasive cancer of the uterine cervix and its use has reduced morbidity and mortality from invasive cancer in various population groups. ${ }^{4,5}$ The assumed accuracy of Pap test still, (80 to $95 \%$ ) has been questioned. Conversely, a false negative rate of the Pap smear has been reported under carefully controlled condition. ${ }^{6-10}$

Simultaneous use of cytological studies and screening colposcopy has been shown to increase cervical cancer detection.

\section{Aims}

- To screen women of 30-45 years for cervical cancer with VIA, Pap smear and Colposcopy.

\section{Objectives}

- To compare and correlate the findings of Pap smear and VIA in detecting premalignant lesions of cervix.

- To compare and correlate the findings of Pap smear and Colposcopy in detecting premalignant lesions of cervix.

\section{METHODS}

A prospective observational study was carried out in 500 women visiting gynecological OPD between 30-45 years (opportunistic screening). The data was collected from Bharati Hospital, OPD, department of obstetrics and gynaecology, in Pune .The purpose and the procedure of the study was explained to them and a written consent was obtained.

\section{Inclusion criteria}

- $\quad$ Age between 30-45 years.

- Previous PAp report (if available) s/o inflammation (done 3-6 months back)

- Cervical ectopy or hypertrophied cervix.

\section{Exclusion criteria}

- With any local (vaginal, cervical) infection or bleeding

- Pregnancy

- IUCD

- Previous surgery on cervix like cautery or LEEP.
For potential candidates after taking detailed history and thorough systemic examination, Pap smear was taken by conventional method and then VIA (visual inspection of cervix with acetic acid) was carried out.

Pap smear was taken by Ayers spatula with proper SCJ (Squamo-Columnar Junction) scraping for satisfactory smear, fixing and staining was done by conventional method.

Pap smear is interpreted as per Bethesda classification. ${ }^{11}$

Table 1: Bethesda system.

\begin{tabular}{|l|}
\hline \multicolumn{1}{|c|}{ Bethesda system } \\
\hline Within normal limits \\
\hline Infections (Org. should is specified) \\
\hline Reactive and reparative changes \\
\hline Squamous cell abnormalities \\
\hline ASC-US \\
ASC-H \\
\hline LSIL \\
\hline HSIL \\
\hline Squamous cell carcinoma. \\
\hline
\end{tabular}

\section{VIA}

Cervix was visualized thoroughly after putting speculum (don't use any antiseptic solution) for any nabothian cyst, polyp, infection, leukoplakia, growth. 5\% acetic acid (AA) was applied to cervix for $1 \mathrm{~min}$. VIA is interpreted as either negative or positive.

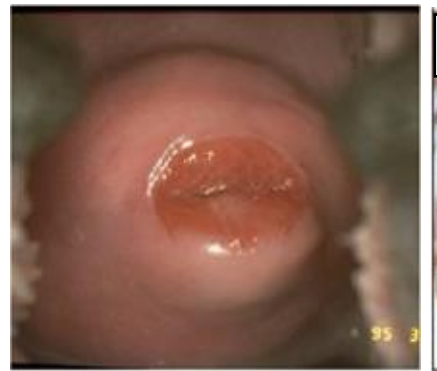

VIA negative

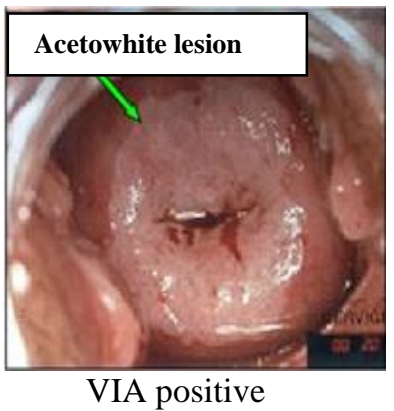

VIA positive
Figure 1: VIA.

\section{Colposcopy}

All VIA positive patients were further screened by colposcopy, in 3 steps,

- Normal saline application

- $5 \%$ Acetic acid application

- Lugol's iodine application.

Results of VIA, Pap smear and Colposcopy were then compared and correlated by using statistical methods of analysis. 
Table 2: On colposcopy patient were scored as per Reid'S colposcopy index.

\begin{tabular}{|c|c|c|c|}
\hline Colposcopic signs & Zero point & One point & Two points \\
\hline Colour & $\begin{array}{l}\text { Low-intensity acetowhitening (not } \\
\text { completely opaque); indistinct } \\
\text { acetowhitening; transparent or translucent } \\
\text { acetowhitening beyond the margin of the } \\
\text { transformation zone Pure snow-white colour } \\
\text { with intense surface shine }\end{array}$ & $\begin{array}{l}\text { Intermediate shade - } \\
\text { grey/white colour and } \\
\text { shiny surface (most } \\
\text { lesions should be scored } \\
\text { in this category) }\end{array}$ & $\begin{array}{l}\text { Dull, opaque, oyster white; } \\
\text { grey }\end{array}$ \\
\hline $\begin{array}{l}\text { Lesion margin and } \\
\text { surface configuration }\end{array}$ & $\begin{array}{l}\text { Microcondylomatous or micro papillary } \\
\text { contour } \\
\text { Flat lesions with indistinct margins } \\
\text { Feathered or finely scalloped margins } \\
\text { Angular, jagged lesions } \\
\text { Satellite lesions beyond the margin of the } \\
\text { transformation zone }\end{array}$ & $\begin{array}{l}\text { Regular-shaped, } \\
\text { symmetrical lesions with } \\
\text { smooth, straight outlines }\end{array}$ & $\begin{array}{l}\text { Rolled, peeling edges }{ }^{2} \\
\text { Internal demarcations } \\
\text { between areas of differing } \\
\text { colposcopic appearance-a } \\
\text { central area of high-grade } \\
\text { change and peripheral area } \\
\text { of low-grade change }\end{array}$ \\
\hline Vessels & $\begin{array}{l}\text { Fine/uniform-calibre vessels }{ }^{4} \text { - closely and } \\
\text { uniformly placed Poorly formed patterns of } \\
\text { fine punctuation and/or mosaic } \\
\text { Vessels beyond the margin of the } \\
\text { transformation zone } \\
\text { Fine vessels within microcondylomatous or } \\
\text { micro papillary lesions }\end{array}$ & Absent vessels & $\begin{array}{l}\text { Well defined coarse } \\
\text { punctation or mosaic, } \\
\text { sharply demarcated }{ }^{5} \text { - and } \\
\text { randomly and widely } \\
\text { placed }\end{array}$ \\
\hline Iodine staining & $\begin{array}{l}\text { Positive iodine uptake giving mahogany- } \\
\text { brown color } \\
\text { Negative uptake of insignificant lesion, i.e., } \\
\text { yellow staining by a lesion scoring three } \\
\text { points or less on the first three criteria } \\
\text { Areas beyond the margin of the } \\
\text { transformation zone, conspicuous on } \\
\text { colposcopy, evident as iodine-negative areas } \\
\text { (such areas are frequently due to } \\
\text { parakeratosis) }\end{array}$ & $\begin{array}{l}\text { Partial iodine uptake - } \\
\text { variegated, speckled } \\
\text { appearance }\end{array}$ & $\begin{array}{l}\text { Negative iodine uptake of } \\
\text { significant lesion, i.e., } \\
\text { yellow staining by a lesion } \\
\text { already scoring four points } \\
\text { or more on the first three } \\
\text { criteria }\end{array}$ \\
\hline
\end{tabular}

\section{RESULTS}

Out of 500 women, $364(72.8 \%)$ women were VIA negative and $136(27.2 \%)$ were VIA positive.

! Sample of 10 women were not taken because of bleeding. Diagnosis of two women was unsatisfactory. !! Diagnosis of 8 women was unsatisfactory.

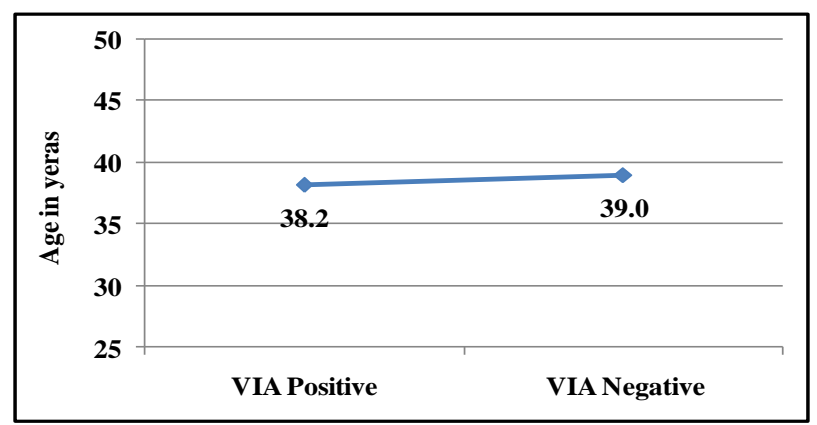

Figure 2: Mean age of the women by result of VIA.

Differences in mean age of the women from VIA positive and negative group were not statistically significant (compared using independent sample $\mathrm{t}$ test $)(\mathrm{t}=1.228$, $\mathrm{p}>0.05)$.
Table 3: Result of VIA, Pap smear, colposcopy examination among the study group.

\begin{tabular}{|llll|}
\hline Examination & Diagnosis & $\begin{array}{l}\text { Number } \\
\text { of women }\end{array}$ & Percentage \\
\hline VIA ( $\mathrm{n}=500)$ & Negative & 364 & 72.8 \\
\hline & Positive & 136 & 27.2 \\
\hline $\begin{array}{l}\text { Pap smear of } \\
\text { VIA negative } \\
(\mathrm{n}=364)\end{array}$ & Negative & 364 & 100.0 \\
\hline $\begin{array}{l}\text { Pap smear of } \\
\text { VIA positive } \\
(\mathrm{n}=124 \text { !) }\end{array}$ & NILM & 82 & 66.1 \\
\hline & LSIL & 26 & 21.0 \\
\hline & HSIL & 16 & 12.9 \\
\hline $\begin{array}{l}\text { Colposcopy } \\
\left(\mathrm{n}=1288^{! !}\right)\end{array}$ & Normal & 16 & 12.5 \\
\hline & Cervicitis & 42 & 32.8 \\
\hline & Ectopy & 11 & 8.6 \\
\hline & CIN I & 15 & 11.7 \\
\hline & CINI- II & 27 & 21.0 \\
\hline & CIN II- III & 17 & 13.2 \\
\hline
\end{tabular}


Table 4: Correlation of age with result of VIA.

\begin{tabular}{|llll|l|}
\hline VIA & $\begin{array}{l}\text { Age group } \\
\text { years }\end{array}$ & $\begin{array}{l}36-40 \\
\text { years }\end{array}$ & $\begin{array}{l}41-45 \\
\text { years }\end{array}$ & $\begin{array}{l}\text { Total } \\
(500)\end{array}$ \\
\hline Negative & $114(31.3)$ & $94(25.8)$ & $156(42.9)$ & $364(72.8)$ \\
\hline Positive & $52(38.2)$ & $28(20.6)$ & $56(41.2)$ & $136(27.2)$ \\
\hline $\begin{array}{l}\text { Pearson chi-square test } \\
\text { significant as } \mathrm{p}>0.05 .\end{array}$
\end{tabular}

Table 5: Correlation of age with result of Pap smear in VIA positive women.

\begin{tabular}{|lllll|}
\hline Pap & \multicolumn{4}{c}{ Age group } \\
smear & $\begin{array}{l}30-35 \\
\text { years }\end{array}$ & $\begin{array}{l}36-40 \\
\text { years }\end{array}$ & $\begin{array}{l}41-45 \\
\text { years }\end{array}$ & $\begin{array}{l}\text { Total } \\
(124)\end{array}$ \\
\hline NILM & $38(46.3)$ & $18(22.0)$ & $26(31.7)$ & $82(66.1)$ \\
\hline LSIL & $7(26.9)$ & $6(23.1)$ & $13(50.0)$ & $26(21.0)$ \\
\hline HSIL & $4(25.0)$ & $1(6.3)$ & $11(68.8)$ & $16(12.9)$ \\
\hline
\end{tabular}

Pearson chi-square test $\chi^{2}=9.959 \mathrm{p}=0.041 * ; *$ Statistically significant as $\mathrm{p}<0.05$.

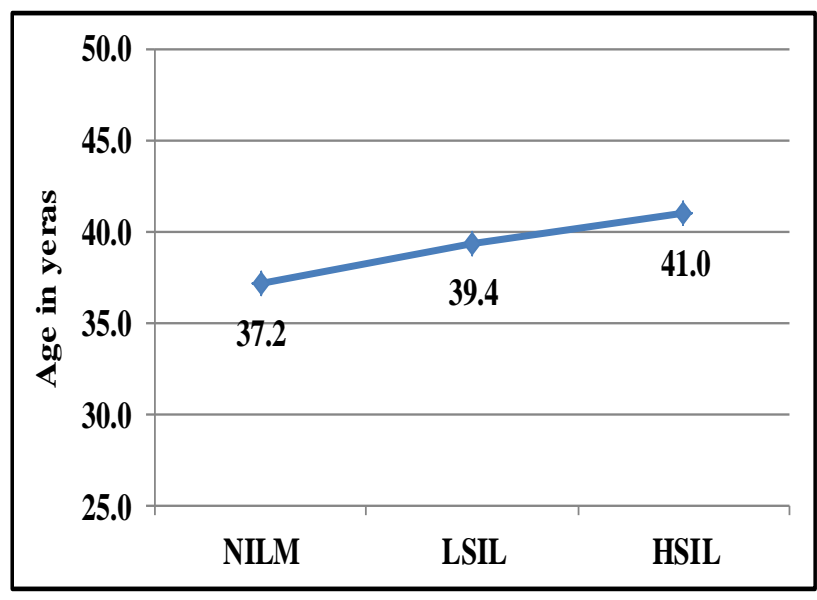

Figure 3: Mean age of the women by result of Pap smear.

Table 6: Correlation of age with result of colposcopy examination.

\begin{tabular}{|lllll|}
\hline Colposcopy & $\begin{array}{l}\text { Age group } \\
30-35 \\
\text { years }\end{array}$ & $\begin{array}{l}36-40 \\
\text { years }\end{array}$ & $\begin{array}{l}41-45 \\
\text { years }\end{array}$ & $\begin{array}{l}\text { Total } \\
(136)\end{array}$ \\
\hline Negative & $36(50.7)$ & $15(21.1)$ & $20(28.2)$ & $71(52.2)$ \\
\hline Positive & $16(24.6)$ & $13(20.0)$ & $36(55.4)$ & $65(47.8)$ \\
\hline $\begin{array}{l}\text { Pearson chi-square test } \\
\text { significant as }<<0.05\end{array}$ & $\chi^{2}=12.166$ & p=0.002*.* & Statistically \\
\hline
\end{tabular}

Comparison among mean age of the women across the groups using ANOVA test indicated statistically significant increase in age $(\mathrm{F}=5.326, \mathrm{p}<0.05)$.

Differences in mean age of the women from Colposcopy positive and negative group were statistically significant (compared using independent sample $\mathrm{t}$ test $)(\mathrm{t}=3.697$, $\mathrm{p}<0.000)$.

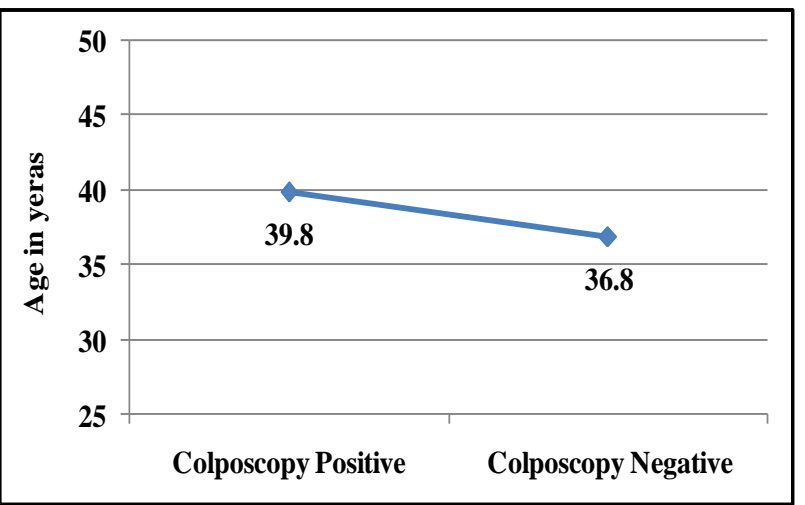

Figure 4: Mean age of the women by result of Colposcopy.

Table 7: Correlation between VIA and Pap smear.

\begin{tabular}{|c|c|c|c|c|}
\hline \multirow{2}{*}{ VIA } & \multicolumn{3}{|c|}{ Pap smear } & \multirow{2}{*}{$\begin{array}{l}\text { Pearson chi- } \\
\text { square test }\end{array}$} \\
\hline & Positive & Negative & Total & \\
\hline Positive & $\begin{array}{l}42 \\
(33.9)\end{array}$ & $\begin{array}{l}82 \\
(66.1)\end{array}$ & $\begin{array}{l}124 \\
(24.8)\end{array}$ & \multirow{2}{*}{$\begin{array}{l}\chi 2=32.9699 \\
\mathrm{p}=0.000 *\end{array}$} \\
\hline Negative & $\begin{array}{l}0 \\
(0.0)\end{array}$ & $\begin{array}{l}364 \\
(100.0)\end{array}$ & $\begin{array}{l}364 \\
(72.8)\end{array}$ & \\
\hline
\end{tabular}

* Statistically significant as $\mathrm{p}<0.05$

Table 8: Correlation between Pap smear and Colposcopy.

\begin{tabular}{|c|c|c|c|c|}
\hline \multirow{2}{*}{$\begin{array}{l}\text { Pap } \\
\text { smear }\end{array}$} & \multicolumn{3}{|c|}{ Colposcopy } & \multirow{2}{*}{$\begin{array}{l}\text { Pearson chi- } \\
\text { square test }\end{array}$} \\
\hline & Positive & Negative & Total & \\
\hline Positive & $39(70.9)$ & $3(4.3)$ & $82(66.1)$ & \multirow{2}{*}{$\begin{array}{l}\chi^{2}=60.536 \\
p=0.000^{*}\end{array}$} \\
\hline Negative & $16(29.1)$ & $66(95.7)$ & $42(33.9)$ & \\
\hline
\end{tabular}

Table 9: Predictive value of colposcopy.

\begin{tabular}{|c|c|c|c|}
\hline \multirow{2}{*}{ Pap smear } & \multicolumn{2}{|c|}{ Colposcopy } & \multirow{2}{*}{ Total } \\
\hline & Positive & Negative & \\
\hline Positive & 39 (a) & 3 (b) & $42(a+b)$ \\
\hline Negative & $16(c)$ & $66(d)$ & $82(c+d)$ \\
\hline Total & $55(a+c)$ & $69(b+d)$ & 124 \\
\hline
\end{tabular}

Sensitivity $=a /(a+c)$ X $100=39 / 55$ X $100=70.9$;

Specificity $=d /(b+d) \times 100=66 / 69 \times 100=95.6$; Predictive value of positive test $=a /(a+b) X 100=39 / 42$ X $100=92.8$ Predictive value of negative test $=\mathrm{d} /(\mathrm{c}+\mathrm{d}) \mathrm{X} 100=66 / 82 \mathrm{X}$ $100=80.5 ;$ Percentage of false negative $=\mathrm{c} /(\mathrm{a}+\mathrm{c}) \mathrm{X} 100=16$ / $55 \times 100=29.0$; Percent of false positive $=b /(b+d) \times 100=$ $3 / 69 \times 100=4.34$

\section{DISCUSSION}

VIA is easy with on the spot result screening tool for cervical lesions. Conventional Pap smear has its own limitations like non adequacy of smear, endocervical cells not included, air drying of slide or fixation issues with slide. Colposcopy is an excellent means of evaluating abnormal cervical cytology.

We compared the detection rate of cervical intraepithelial neoplasia in VIA positive women by Pap smear and 
Colposcopy. The population screened in this study varied in age with no preference for any specific group.

In our study after correlating results of VIA with woman's age, (negative/positive) it does not have any correlation. Even differences in mean age for both test results were statistically not significant (Figure 2).

On the other hand there is statistically significant correlation with higher age and advanced lesion on Pap test by Bethesda classification. NILM, LSIL, HSIL in increasing trends (Table 5, Figure 3).

Even there is statistically significant correlation with higher age and advanced lesion on Colposcopy results as CIN I, CIN I-II, CIN II-III in increasing trends (Table 6, Figure 4).

Results obtained from the study after comparing VIA and Pap showed that though specificity of VIA is less (48.4\%) as compared to Pap specificity $(70 \%)$, sensitivity of VIA $(100 \%)$ is almost comparable with sensitivity of Pap (90.2\%) and VIA has 100\% NPV (negative predictive value) in this study.

Results obtained from comparing Pap smear with Colposcopy, it showed that sensitivity of colposcopy is almost $100 \%$ as compared to that of Pap sensitivity (90.2) and NPV of colposcopy is $100 \%$ and that of pap is $80 \%$. Pap has better specificity $(95 \%)$ as compared to colposcopy (18\%) which is almost comparable with other study results quoted below.

Singh S et al compared 100 women with pap and colposcopy and concluded that colposcopy is more sensitive (95\%) than the Pap smear (20\%), whereas specificity is less compared to $91.25 \%$ of the Pap smear. The predictive value of both the tests were comparable, i.e., $36 \%$ for Pap smear and $39.58 \%$ for colposcopy. ${ }^{12}$

Hegade D et al studied 225 cases and concluded that VIA and Pap sensitivity and specificity are almost comparable. ${ }^{13}$

Shuchi et al compared 200 patients with VIA, VILI and Pap, concluded that VIA and VILI had sensitivity comparable to Pap smear and can therefore be a suitable potential alternative/adjunctive screening test not only in resource-poor settings but also in well-equipped centers. ${ }^{14}$

Asmitha et al studied 52 patients, concluded that colposcopy has better sensitivity as compared with pap, but pap has better specificity. ${ }^{15}$

Our findings in this prospective study show that colposcopy is definitely more sensitive than the papanicolaou smear as a screening tool for CIN. More than four times as many CIN lesions were identified by colposcopy than with papanicolaou smears. The papanicolaou smear was however more specific as a screening tool for CIN than was colposcopy.

\section{CONCLUSION}

Even though cytology is available VIA can be used as a primary screening tool in detection of premalignant lesions of uterine cervix which is cost effective, and has on the spot results. Colposcopy should be offered to all VIA positive lesions so that even low grade lesions of cervix can be diagnosed and earlier conservative management can be offered to higher lesions.

Funding: No funding sources

Conflict of interest: None declared

Ethical approval: The study was approved by the Institutional Ethics Committee

\section{REFERENCES}

1. Parkin M. Personal communication, IARC; 2000.

2. PATH Program for Appropriate Technology in Health. Preventing cervical cancer in low-resource settings. Outlook. 2000;18(1):1-8.

3. Moss SF, Blaser MJ. Mechanisms of disease: inflammation and origins of cancer. Nat Clin Pract Oncol. 2005;2:907.

4. Stenkvist B, Bergstrom, Elkland G, Fox CH. Papanicolaou: smear screening and cervical cancer: What can you expect? JAMA. 1984;252:1423.

5. Day NE. Effect of cervical cancer screening in Scandinavia. Obstet Gynecol. 1984;63:714.

6. Morrell ND, Taylor JR, Snyder RN, Ziel HK, Saltz A, Willie S. False negative cytology rates in patients in whom invasive cervical cancer subsequently developed. Obstet Gynecol. 1982;60:42.

7. Berkowitz RS, Ehrmann RL, LaVizo-Mourey R. Invasive cervical cancer in young women. Gynecol Oncol. 1979;8:311.

8. Richart RM. Screening techniques for cervical neoplasia. Clin Obstet Gynecol. 1979;22:701.

9. Richart RM. Current concepts in obstetrics and gynaecology. The patient with an abnormal Pap smear screening techniques and management. N Engl J Med. 1980;302(6):332-4.

10. Richart RM. Evaluation of the true false negative rate in. cytology. Am J Obstet Gynecol. 1964;89:723.

11. Nayar R, Wilbur DC. The Pap test and bethesda 2014. Acta Cytologica. 2015;59:121-32.

12. Singh SL, Dastur NA, Nanavati MS. A comparison of colposcopy and papanicolaou smear : sensitivity, specificity and predictive value. BHJ. 2010.

13. Hegde D, Shetty H, Shetty PK, Rai S. Diagnostic value of acetic acid comparing with conventional Pap smear in the detection of colposcopic biopsyproved CIN. J of Can Res and Ther. 2011;7(4):4548.

14. Consul S, Agrawal A, Sharma H, Bansal A, Gutch M, Jain N. Comparative study of effectiveness of Pap 
smear versus visual inspection with acetic acid and visual inspection with Lugol's iodine for mass screening of premalignant and malignant lesion of cervix. Indian J Med Pediatric Oncol. 2012;33(3):161-5.
15. Ashmita D, Shakuntala PN, Shubha RR, Sharma SK, Geethanjali S. Comparison and correlation of PAP smear, colposcopy and histopathology in symptomatic women and suspicious looking cervix in a tertiary hospital care centre. IJHSR. 2013;3(5):50-9.

Cite this article as: Talathi M, Wagh G. Comparison and correlation of visual inspection with acetic acid, papanicolaou smear and colposcopy in detection of precancerous cervical lesions. Int J Reprod Contracept Obstet Gynecol 2016;5:3384-9. 